calculate the percentage of maternal clearance which passed to fetuses.

$$
\underset{\mathrm{MCR}_{\mathrm{M}} \times 3 \mathrm{hr} \times \mathrm{Y}_{\mathrm{M}}}{\mathrm{Y}} \times 100 \quad \mathrm{MCR}_{\mathrm{M}}=\mathrm{K}_{\mathrm{M}}+\mathrm{K}_{\mathrm{f}} .
$$

We calculated that $\mathrm{K}_{\mathrm{f}}$ was $0.81 \pm 0.10 \%$ of maternal clearance/litter weight (mean \pm SEM). Therefore: $K_{f}=0.066 \pm$ $0.007 \mathrm{ml} / \mathrm{hr} / 100 \mathrm{~g}$ body weight $(0.045 \pm 0.005 \mathrm{ng} \mathrm{T} / \mathrm{hr} / 100 \mathrm{~g}$ body weight $) ; \mathrm{K}_{\mathrm{s}+1}=8.12 \pm 0.80 \mathrm{ml} / \mathrm{hr} / 100 \mathrm{~g}$ body weight $(5.54$ $\pm 0.54 \mathrm{ng} \mathrm{T}_{3} / \mathrm{hr} / 100 \mathrm{~g}$ body weight $) ; \mathrm{K}_{\mathrm{r}}$. $\mathrm{K}_{\mathrm{Fo}}$, and $\mathrm{VF}$ are unknown, but we may assume that they are equal to zero since there is no $T_{3}$ in the fetal serum.

\section{REFERENCES AND NOTES}

1. Chopra, J. J.. Ho, R. S., and Lam R.: An improved radioimmunoassay of triiodothyronine in serum: Its application to clinical and physiological studies. J. Lab. Clin. Med., 80: 729 (1972).

2. Dussault, J. H., Hobel, C. J.. DiStephano, J. J., Ill, Erenberg, A.. and Fisher. D. A.: Triiodothyronine turnover in maternal and fetal sheep. Endocrinology, 90: 1301 (1972).

3. Dussault, J. H., and Labrie, F.: Development of the hypothalamic-pituitarythyroid axis in the neonatal rat. Endocrinology, 97: 1321 (1975).

4. Editorial: Transplacental passage of thyroid hormones. N. Engl. J. Med., 277: 486 (1967)

5. Fisher, D. A., Morris, M. D.. Lehman, H. and Lackey, C.: Studies of butanol extractable iodine by the ceric oxydation method. Anal. Biochem., 7: 37 (1964).

Copyright o 1977 International Pediatric Research Foundation, Inc
6. Fisher. D. A., and Dussault, J. H.: Development of mammalian thyroid gland. In: M. A. Greer and D. H. Solomon: Handbook of Physiology, Vol. III, American Physiological Society, Washington, D.C., (1974).

7. Fisher, D. A., Dussault, J. H., Erenberg, A.. and Law, R. W.: Thyroxine and triiodothyronine metabolism in maternal and fetal sheep. Pediat. Res.. 6 : 894 (1972).

8. Geloso, J. P.: Fonctionnement de la thyroide et corrélations thyréohypophysaires chez le foetus de rat. Ann. Endocrinol., T.28(I): 5 (1967).

9. Knobil, E., and Josinovich, J. B.: Placental transfer of thyrotropin hormone, thyroxine, triiodothyronine and insulin in rat. Ann. N. Y. Acad. Sci., 75: 895 (1958).

10. Nataf, B. Sfez, M. Michel, R., and Roche, J.: Sur la perméabilité du placenta à la L-3:5:3'-triiodothyronine. C. R. Soc. Biol. Paris, /50: (1956)

11. Postel, S.: Placental transfer of perchlorate and triiodothyronine in the guinea pig. Endocrinology, 60: 53 (1957)

12. Snedecor, G. W., and Cochran, W. G.: Statistical Methods, Ed. G (Iowa State College Press. Ames. Iowa, 1967).

13. Sterling. K., and Chodos, R. B.: Radiothyroxine turnover. Studies in myxedema, thyrotoxicosis and hypermetabolism without endocrine disease. J. Clin. Invest.. 35: 806 (1956).

14. Varma, S. K.: The effect of maternal triiodothyronine $\left(\mathrm{T}_{3}\right)$ administration on the fetal and newborn rats [Abstract]. American Thyroid Association Meeting, St. Louis, September 1974.

15. Canadian Breeding Farms, St.-Constant, Laprairic

16. This work was supported by Medical Research Council of Canada Grant MA 5730.

17. Requests for reprints should be addressed to: J. H. Dussault. M.D., M.Sc, Laboratoire de Recherches in Endocrinologie et Metabolisme, Le Centre Hospitalier de l'Université Laval, 2705, boul. Laurier, Québec GIV 4G2 (Canada).

18. Reccived for publication April 20, 1976.

19. Accepted for publication August 2, 1976

\title{
Serum Plasminogen and Lung Surfactant in the Respiratory Distress Syndrome
}

\author{
ALLAN D. SINGER, DONALD W. THIBEAULT, ${ }^{(34)}$ CALVIN J. HOBEL, AND DOUGLAS C. HEINER \\ Divisions of Perinatal Medicine and Immunology-Allergy, Deparments of Pediatrics and Obstetrics, Harbor \\ General Hospital, UCLA School of Medicine, Torrance, California, USA
}

\section{Summary}

Plasminogen, total protein, and surface-active material were measured in amniotic fluid in 112 pregnancies at 11-42 weeks' gestation. In 65 of these pregnancies, cord blood was also analyzed for serum plasminogen and total protein. Plasminogen was detected in 25 of 114 amniotic fluid samples, and 23 came from pregnancies of less than 37 weeks' gestation. Plasminogen was found in 15 of 32 amniotic fluid samples from pregnancies with complications, but only in 10 of 80 "uncomplicated" pregnancies. The mean cord serum plasminogen was relatively constant in births or abortuses of 17 to 30 weeks' gestation, but was present in increasing amounts in births of gestational ages from 30 to 40 weeks. The concentration of plasminogen in cord serum was directly related to the cord total protein $(r=0.7513, P<$ 0.001). The cord plasminogen concentration was significantly higher in infants with a positive foam stability test $(5.6 \pm 0.3 \mathrm{mg} /$ $100 \mathrm{ml}$ ) than in the combined group of infants with negative and intermediate tests $(4.3 \pm 0.16, P<0.005)$. However, infants with a positive foam stability also had a significantly greater gestational age than infants with a negative or intermediate foam stability test. With one exception, infants with a low cord plasminogen (below $4 \mathrm{mg} / 100 \mathrm{ml}$ ) developed respiratory distress syndrome (RDS) only if amniotic fluid surfactant was low. The data suggest that low levels of serum plasminogen are correlated with severe lung disease only in the presence of surfactant deficiency.

\section{Speculation}

In infants that develop the respiratory distress syndrome, many serum proteins are found in diminished concentration in the umbilical cord blood. Interest has naturally focused on the antiproteinases because a functional deficiency in these could contribute to fibrin deposition, a characteristic finding in hyaline membranes. However, it has been difficult to determine whether antiproteinases are low because of increased consumption or as a result of nonspecific leakage of many proteins from the blood. Even the evidence of a selectively greater depletion of $\alpha_{1}$ antitrypsin than the larger molecule, plasminogen, or other cord 
serum proteins may simply represent a preferential molecular sieving of small molecules. If another serum protein of similar or lesser molecular weight than the relatively small $\alpha_{1}$-antitrypsin were simultaneously studied in the cord blood, it should be possible to answer the question of a selective depletion.

If a greater deficiency of serum $\alpha_{1}$-antitrypsin than of the second protein of similar size were found in RDS, this would favor a specific depletion of the antiproteinase. If the two proteins were equally deficient or if a smaller protein were more deficient, there would be little evidence for a specific deficiency of $\alpha_{1}$-antitrypsin.

The formation of pulmonary hyaline membranes in preterm infants is frequently associated with RDS. Studies of the membranes have established the presence of constituents originating from the blood. Oneof the constituents is fibrin, which has been detected by immunofluoresence (17) and electron microscopy (28). A defective or immature fibrinolytic system has been suggested as a likely mechanism in the pathogenesis of the retained fibrin in the membranes $(1,2,4,21)$

The evidence supporting defective fibrinolysis in the pathogenesis of RDS is extensive, but not conclusive. Generation of fibrinolytic activity depends on adequate quantities of plasminogen and plasminogen activators (3). An increased concentration of inhibitor of plasminogen activator in the lungs of infants with hyaline membrane disease has been reported by Lieberman (20). He detected this inhibitor in placental tissue and postulated that it was released into the fetal circulation and was subsequently deposited in fetal lung tissue. However, defective tissue plasminogen activation in the lungs of infants who died with RDS was not found by Ekelund et al. (11). The question remains open.

In a recent double blind study, Ambrus et al. (3) reported that preterm infants given intravenous plasminogen had a lowered incidence of severe RDS. This suggests that the preterm infant has little difficulty converting plasminogen to plasmin, presumably with help from its own lung plasminogen activator. Moreover, this finding suggests that a deficiency of plasminogen may predispose to fibrin retention in the alveoli of infants with hyaline membranes $(2,4,10)$.

Taylor and Abrams (27), in an interesting study, demonstrated that the addition of fibrinogen to surfactant in vitro greatly reduced its surface-active properties. Fibrinogen is found in the alveoli of infants who die with RDS (15). To our knowledge there are no data regarding the effects of fibrinogen on alveolar surface activity in vivo.

It is possible that surfactant deficiency is related to a deficiency of plasminogen in cord serum since both of these have been reported to be related to the respiratory distress syndrome $(2,4,6,9,18)$. However, it is possible that either or both of these deficiencies may be a function of immaturity.

The present study was designed to explore a possible relationship between serum plasminogen levels and alveolar surfactant activity as reflected in the amniotic fluid of preterm infants with the respiratory distress syndrome.

\section{MATERIAL AND METHODS}

Amniotic fluid total protein, plasminogen, and surface active material were measured in 112 pregnancies (114 samples) at $11-$ 42 weeks' gestation. The amniocenteses were performed on patients undergoing saline therapeutic abortion, on patients with high risk pregnancies, and to determine the amniotic fluid surfactant activity in women undergoing elective caesarian sections (31). Amniotic fluid was obtained by transabdominal amniocentesis or needle aspiration through bulging forewaters.

It was also possible to obtain cord blood in 65 of these pregnancies in which the amniotic fluid had been obtained within $24 \mathrm{hr}$ of delivery. The cord serum plasminogen and total protein were measured.
Respiratory distress syndrome was diagnosed if all of the following criteria were met: $(l)$ a Silverman-Anderson retraction score of greater than 4 at $4 \mathrm{hr},(2)$ an audible expiratory grunt at $4 \mathrm{hr} .(3)$ an increased ambient oxygen concentration for $48 \mathrm{hr}$ or more to maintain a $\mathrm{PaO}_{2}$ greater than $40 \mathrm{~mm} \mathrm{Hg} \mathrm{(4)}$ radiologic evidence of RDS. consisting of a diffuse reticulogranular pattern with prominent air bronchograms. Some infants had mild respiratory distress without fulfilling all of the above criteria. This group of infants was designated as having respiratory distress (RD). The following criteria was used to define this group: (1) Silverman-Anderson retraction score greater than 4 at $4 \mathrm{hr},(2)$ an increased ambient oxygen concentration for more than 12 hr to keep the $\mathrm{PaO}_{2}$ greater than $40 \mathrm{~mm} \mathrm{Hg}$. (3) absence of a specific clinical or radiologic diagnosis of lung or heart disease. The RD group did include those infants with radiologic changes characteristic of transient tachypnea of the newborn (5). This separation of infants with respiratory problems into two types if, of course, arbitrary; in some instances, RD is most likely a mild form of RDS.

Total protein in amniotic fluid was determined by the Lowry technique (22) and in the cord serum by refractometry. Plasminogen concentrations in both amniotic fluid and sera were determined by the Mancini technique, using radial immunodiffusion plates obtained from Behring Diagnostics (30).

In order to minimize day to day and specimen to specimen procedural variations in the current study, the same set of four standards for plasminogen were used throughout the study; care was taken to insure equal filling of wells by employing an accurate microliter pipette. All tests were allowed to diffuse to equilibrium for $72 \mathrm{hr}$, and all reservoirs were utilized in each immunodiffusion chamber. This method was accurate to within $\pm 15 \%$ on duplicate determinations. The measurement of plasminogen by immunodiffusion has a distinct advantage over measurement by an enzymatic assay since the enzymatic activity may be influenced by inhibitors of plasminogen (16). Plasminogen inhibitors may be present in varying concentrations in cord serum, a feature which will not interfere with the immunochemical test. The immunochemical test measures the sum of plasminogen and plasmin in the samples.

Surface-active material was assessed by the foam stability test as described by (lements et al. (9). Volumes of amniotic fluid of $1.0,0.75,0.50$, and $0.25 \mathrm{ml}$ were pipetted into tubes, 14 by 100 $\mathrm{mm}$, labeled $1 / 1,1 / 1,3,1 / 2$, and $1 / 4$, respectively. Volumes of $0.25,0.50$, and $0.75 \mathrm{ml}$ of $0.9 \%$ saline were pipetted into tubes 2,3 , and 4 , respectively. One milliliter of $95 \%$ ethanol was added to each tube. The tubes were capped with clean rubber stoppers and shaken vigorously for 15 sec by the clock and then

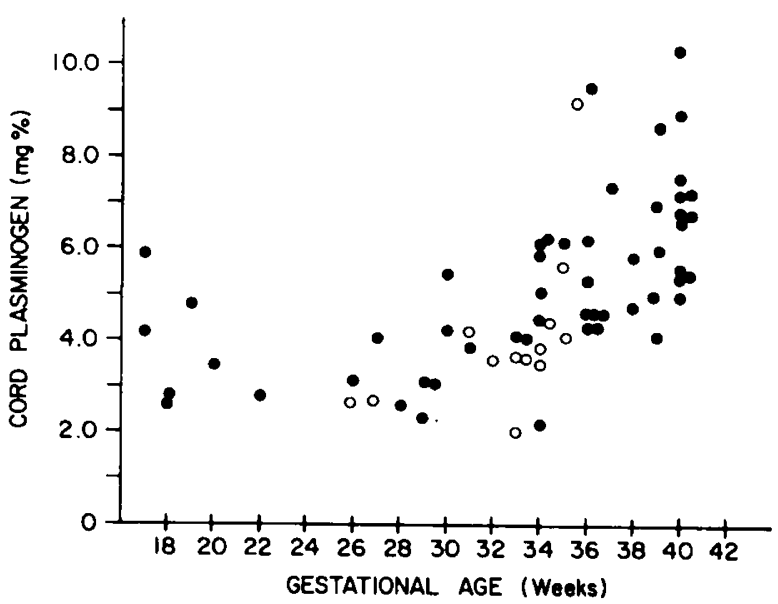

Fig. 1. The relationship of cord serum plasminogen to gestational age. The plasminogen remains relatively constant from 17-30 weeks' gestation and then rises with increasing gestation. Infants with the respiratory distress syndrome are depicted by open circles $(O)$. 


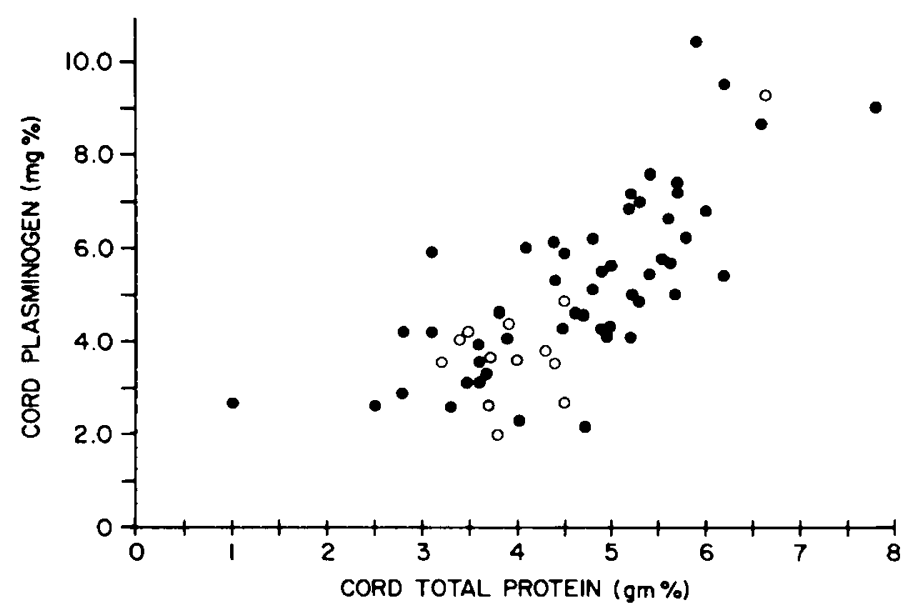

Fig. 2. The cord plasminogen concentration is directly and linearly related to the core total protein $(r=0.7513 ; P<0.001)$. The regression equation is: cord plasminogen (milligrams per $100 \mathrm{ml}$ ) $=1.19$ total protein (grams per $100 \mathrm{ml})-0.47$. Infants with the respiratory distress syndrome are depicted by open circles $(O)$.

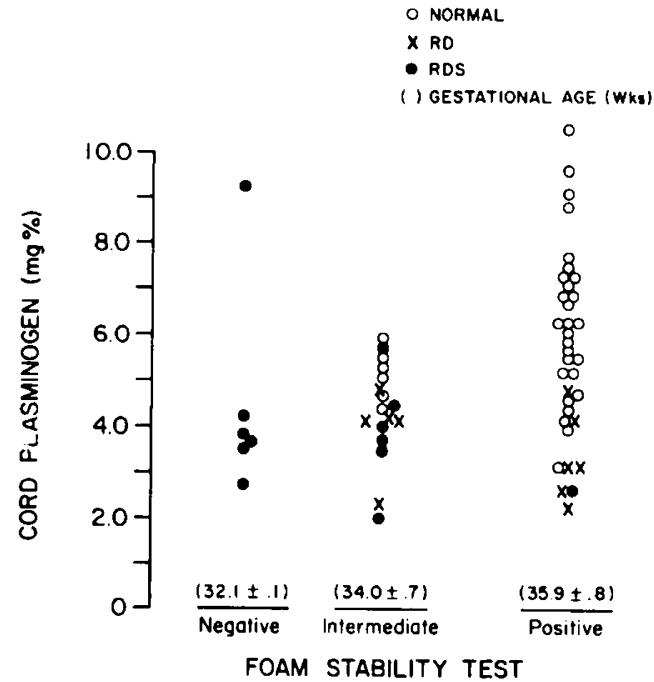

Fig. 3. The relationship of the cord plasminogen concentration to amniotic fluid surface active material as assessed by the foam stability test in infants 26-40 weeks' gestation. The mean plasminogen concentration was significantly lower in infants with intermediate tests or negative tests combined with intermediate tests compared with infants with positive foam stability tests. The mean gestational age was also greater in the infants with a positive foam stability test. Shown are plasminogen mean \pm SEM.

placed vertically in a test tube rack. Fifteen minutes later the airliquid interface was examined in each tube for the presence of small, stable bubbles. Bright overhead light was used and the tubes viewed against a flat, black background. A tube was recorded as positive if it showed a complete ring of bubbles in the meniscus. If the tube labeled $1 / 1$ was negative, the test was called negative. If a tube labeled $1 / 1$ or $1 / 1.3$ was positive, then the test was called intermediate; and if a tube labeled $1 / 2$ or $1 / 4$ was positive, then the test was called positive. This test was performed immediately after obtaining the amniotic fluid. Samples of amniotic fluid containing meconium or blood were discarded.

\section{RESULTS}

The mean cord serum plasminogen level remained relatively constant from 17-30 weeks' gestation and then gradually rose with increasing gestation until term (Fig. 1). The concentration of plasminogen was related to the cord total protein concentration $(r=0.7513: P<0 .(0) 1)$, rising with increasing levels of cord total protein (Fig. 2). The cord plasminogen to total protein ratio was not significantly related to gestational age $(r=0.1346$; $P>0.1)$. Thus, a relative deficiency of serum plasminogen in relation to total protein was not found in the preterm infant.

Figure 3 shows the relationship of cord plasminogen to the amniotic fluid foam stability test. The difference in mean cord plasminogen concentration between the infants with negative foam stability tests $(4.5 \pm 0.9 \mathrm{mg} / 100 \mathrm{ml})$ and those with intermediate $(4.3 \pm 0.3 \mathrm{mg} / 100 \mathrm{ml})$ or positive $(5.6 \pm 0.3 \mathrm{mg} /$ $100 \mathrm{ml})$ foam stability tests did not reach statistical significance. The cord plasminogen concentration, however, was significantly lower in either the group of infants with intermediate tests or the combined group with negative and intermediate tests than in the group with positive tests $(P<0.05$ and $P<0.005)$. However, infants with a positive foam stability test had a greater mean gestational age than infants with negative or intermediate tests $(P<0.025)$, which may play a role in the higher plasminogen levels they exhibited. All infants with RDS, except one, had low amniotic fluid surfactant (a negative or intermediate foam stability test). There were seven infants with a cord plasminogen $(\leq 4.0 \mathrm{mg} / 100 \mathrm{ml})$ who had positive foam stability tests. Six of seven infants were less than 34 weeks' gestation; three of these were very immature, being less than 28 weeks' gestation. Four of the seven had RD and one had RDS. The infant with typical RDS was 26 weeks' gestation and had a low Apgar score, requiring resuscitation at birth.

Figure 4 shows the relationship of cord total protein to the foam stability test. The cord total protein was significantly higher in infants with a positive foam stability test than in infants with intermediate tests or in the combined group with negative and intermediate tests. The lack of a significant difference between the total proteins of infants with negative and positive tests is in part due to the small number of test results in the negative test group and the one infant with the unusually high protein level. As previously mentioned, the infants with positive tests were older than infants with negative or intermediate tests. With one exception, respiratory distress syndrome occurred in infants with a serum protein of $\leq 4.5 / 100 \mathrm{ml}$. All but one of these infants also

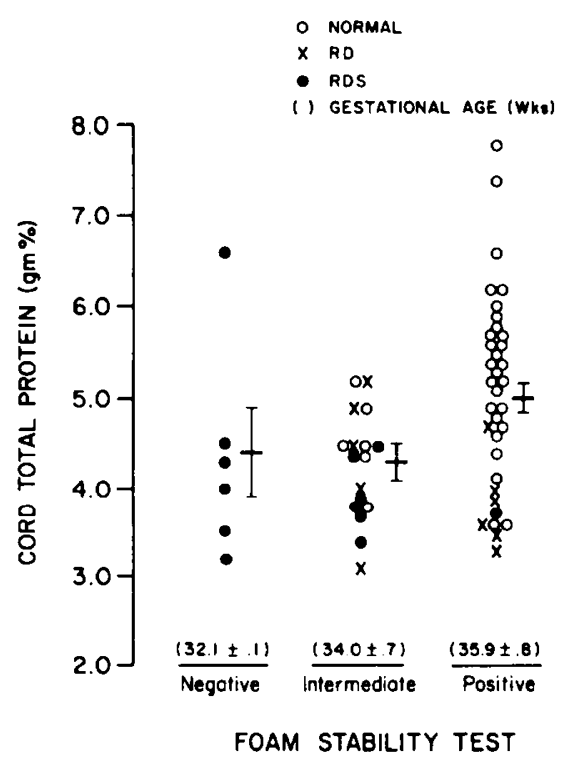

Fig. 4. This figure shows the relationship of cord total protein to the foam stability test. The mean total protein concentration was significantly lower in infants with intermediate tests or negative tests combined with intermediate tests compared to infants with positive foam stability tests. The mean gestational age was also greater in the infants with a positive foam stability test. Shown are cord total protein mean \pm SEM. 
had low amniotic fluid surfactant. There were 10 infants with positive foam stability tests who had a cord total protein of $\leq 4.5$ $\mathrm{g} / 100 \mathrm{ml}$. Nine of the 10 infants were preterm. and 6 were of less than 30 weeks' gestation. Five infants had RD and one had RDS.

Plasminogen was detected in 25 of 114 amniotic fluid samples obtained from pregnancies of 11-42 weeks' gestation. The mean concentration of amniotic fluid plasminogen in these instances was $0.93 \pm 0.1 \mathrm{mg} / 100 \mathrm{ml}$ (range $0.2-2.60)$. Twenty-three of the 25 amniotic fluids with detectable amniotic fluid plasminogen came from the 93 preterm infants studied ( $<37$ weeks gestation). Fifteen of the 25 samples came from the 32 women with pregnancies complicated by bleeding, diabetes, severe precclampsia, RH sensitization, abnormal fetus ECG pattern, or drug abuse. In addition, four were from the pregnancies of less than 25 weeks' gestation. Thus, the presence of more than 0.2 $\mathrm{mg} / 100 \mathrm{ml}$ plasminogen in amniotic fluid was often associated with premature delivery and with complications of pregnancy. Five of 25 samples in which plasminogen was detected had unusually high levels of amniotic fluid total protein $(>0.7 \mathrm{~g} / 100$ $\mathrm{ml}$ ). There was not a significant relationship between plasminogen in amniotic fluid and the respiratory distress syndrome $(P>$ $0.05)$. Also, the relationship between amniotic fluid plasminogen concentration and gestational age was not significant $(r=$ $0.0828 ; P>0.1)$. The level of maternal venous plasminogen did not appear to be related to the level in amniotic fluid $(r=0.268$; $P>0.1)$ or in cord serum $(r=0.049 ; P>0.1)$.

\section{DISCUSSION}

\section{CORD PROTEINS AND RDS}

Plasminogen was detectable in cord blood as early as 17 weeks' gestation. It gradually increased in concentration after 30 weeks' until term when the cord value was half of the maternal level. This rise in cord plasminogen during gestation was associated with a rising cord total protein. A similar relationship between the proteinase inhibitors, $\alpha_{1}$-antitrypsin and $\alpha_{2}$-macroglobulin and cord total protein was observed in a previous study (26).

The relationship of low levels of serum total protein (7). plasminogen (2), antithrombin III (23), $\alpha_{2}$-macroglobulins. and $\alpha_{1}$-antitrypsin $(12-14,19,24,26)$ to the respiratory distress syndrome and hyaline membrane formation in alveoli is well documented. What is not clear is whether these serum proteins are low because of decreased production, increased consumption, or nonspecific leakage into the tissue. Fierer et al. (15) invariably found fibrinogen (a large molecule) in the alveoli of infants with RDS that died, and who had hyaline membranes. In the same infants $\alpha_{1}$-antitrypsin (a small molecule) was not always present in the hyaline membranes. suggesting the possibility of selective loss of fibrinogen into the lung or its specific retention or both.

The incidence of the respiratory distress syndrome in this study as in others was closely related to the low levels of amniotic fluid surface-active material $(9,18)$. Low alveolar surfactant increases the surface tension forces in the alveoli which may predispose to transudation of plasma and accumulation of serum proteins in the alveoli $(8,25,29)$. This could be further aggravated by intrapartum asphyxia and concomitant capillary leakage (26). Infants born with adequate alveolar surfactant should as a group be at less risk for alveolar edema (other determinants being equal), than infants with diminished surfactant.

\section{AMNIOTIC FLUID PROTEINS AND COMPLICATED PREGNANCIES}

Various serum proteins are present in low concentrations in the cord blood of infants who later develop RDS, indicating that factors operative before birth are responsible for the low conentrations. It was shown in a previous study that in infants who develop RDS, the $\alpha_{1}$-antitrypsin is frequently high in amniotic fluid and low in the cord blood (26). This is particularly evident in complicated pregnancies and suggests increased capillary leakage of $\alpha_{1}$-antitrypsin into tissues and amniotic fluid with fetal asphyxia. In infants of complicated pregnancies, the total protein concentration also generally follows the pattern of $\alpha_{1}$-antitrypsin, being low in the cord blood and high in amnitoic fluid. Nevertheless, the $\alpha_{1}$-antitrypsin to total protein ratio was decreased in the cord blood of these complicated pregnancies. This suggested perhaps that $\alpha_{1}$-antitrypsin, because it was a small molecule of $45.00(0)$ molecular weight, was decreased more than the bulk of the protein. However, even $\alpha_{2}$-macroglobulin, which has a molecular weight of 820,000 , was low in the cord blood of complicated pregnancies of less than 32 weeks' gestation; and the $\alpha_{2}$-macroglobulin to total protein ratio was also low in the cord blood of these pregnancies. The more normal levels of $\alpha_{2^{-}}$ macroglobulin found in complicated pregnancies beyond 32 weeks' gestation suggest that the capillaries may be less permeable to large molecules after that age. $\alpha_{2}$-Macroglobulin was not detected in the amniotic fluid in any instance, regardless of the duration of gestation or the presence or absence of complications.

Plasminogen, with a molecular weight of 143,000 , is larger than $\alpha_{1}$-antitrypsin and smaller than $\alpha_{2}$-macroglobulin. It was only found in $22 \%$ of amniotic fluids obtained from pregnancies of 11-42 weeks' gestation compared with $100 \%$ for $\alpha_{1}$-antitryp$\sin$. This low detection rate may be due to its lower concentration in blood (1/20)th of $\alpha_{1}$-antitrypsin) or to its larger size, resulting in less transfer into amniotic fluid, or both. Forty-seven percent of the complicated pregnancies had detectable levels of amniotic fluid plasminogen, suggesting that fetal asphyxia may have led to increased capillary permeability. Thus, the available evidence suggests that before birth there is molecular sieving of proteins, which is a function of both gestational age and the adequacy of fetal oxygenation.

\section{PLASMINOGEN AND RDS}

Ambrus et al. (3) administered plasminogen or placebo intravenously to preterm infants within an hour of birth and recorded the development and the severity of RDS. They concluded that treatment with plasminogen decreased the severity of RDS. Our data suggest that serum plasminogen levels correlate strongly with the maturity of the infant, as does the amniotic fluid surfactant and the incidence of RDS. Low levels of serum plasminogen are related to severe lung disease largely in the presence of surfactant deficiency. Perhaps the infant with surfactant deficiency has a particular need for an effective fibrinolytic system and perhaps passive administration of plasminogen can fill this need, thus permitting a better prognosis in such infants. Further studies to substantitate or refute the value of this form of therapy are indicated.

\section{CONCLUSION}

Plasminogen, total protein, and surface-active material were measured in amniotic fluid in 112 pregnancies at $11-42$ weeks gestation. In 65 of these pregnancies, cord blood was also analyzed for serum plasminogen and total protein. Plasminogen was detected in amniotic fluid in only 25 of 114 samples and was found with increased frequency in complicated pregnancies and in those resulting in delivery of preterm infants. The cord serum plasminogen level remained constant from 17-30 weeks and then rose with increasing gestational age. The concentration of plasminogen was significantly related to the cord total protein. rising with increasing levels of cord total protein. The respiratory distress syndrome occurred in the presence of low amniotic fluid surfactant with a single exception. Low cord plasminogen and total protein were related to lung disease, but the relationship was significant only in the presence of low amniotic fluid surfactant. 


\section{REFERENCES AND NOTES}

1. Ambrus, C. M., Weintraub, D. H., and Ambrus, J. L.: Studies on hyaline membrane disease. HI. Therapeutic trial of urokinase-activated human plasmin. Pediatrics. 38: 231 (1966).

2. Ambrus, C. M., Weintraub, D. H.. Dunphy, D., Dowd, J. E., Pickren, J. W.. Niswander, K. R., and Ambrus, J. L.: Studies on hyaline membrane disease. 1 . The fibrinolysin system in pathogenesis and therapy. Pediatrics, 32: $10(1963)$.

3. Ambrus, C. M.. Weintraub, D. H., Choi, T. S., Eisenberg, B., Staub, H. P. Courey, N. G., Foote, R. J., Goplerud, D. Moesch, R. V. Ray, M. Bross, I. D. J.. Jung, O. S., Mink, I. B., and Ambrus, J. L.: Plasminogen in the prevention of hyaline membrane disease. Amer. J. Dis. Child., 127: 189 (1974).

4. Ambrus, C. M., Weintraub, D. H., Niswander, K. R., and Ambrus, J. L. Studies on hyaline membrane disease. Il. The ontogeny of the fibrinolysin system. Pediatrics, 35: 91 (1965)

5. Avery, M. E. Gatewood, O. E., and Brumley, G.: Transient tachypnea of the newborn. Amer. J. Dis. Child., 111:380 (1966)

6. Avery, M. E., and Mead, J.: Surface properties in relation to atelectasis and hyaline membrane disease. Amer. J. Dis. Child., 95: 517 (1959)

7. Bland. R. D.: Cord-blood total protein level as a screening aid for the idiopathic respiratory distress syndrome. N. Engl. J. Med., 287: 9 (1972).

8. Clements, J. A.: Pulmonary edema and permeability of alveolar membranes. Arch. Environ. Health, 2: 280 (1961).

9. Clements, J. A.. Platzker, A. C. G., Tierney, D. F.. Hobel, C. J., Creasy, R. K. Margolis, A. J., Thibeault, D. W., Tooley, W. H., and Oh, W. Assessment of the risk of the respiratory distress syndrome by a rapid test for surfactant in amniotic fluid. N. Engl. J. Med., 286: 1077 (1972).

10. Ekelund. $\mathrm{H}$., and Finnström. O.: Fibrinolysis in preterm infants and in infants small for gestational age. Acta Paediat. Scand., 61: 185 (1972).

11. Ekelund, H.. Pandolfi, M., Görrell, O.. and Bjernstad, A.: Fibrinolytic activity in lung tissue from neonates with hyaline membrane disease. Acta Paediat. Scand., 62:149 (1973).

12. El-Bardesy, M. W.. and Johnson, A. M.: Serum proteinase inhibitors in infants with hyaline membrane diseases. J. Pediat., 81: 579 (1972).

13. Evans, H. E.. Keller, S., and Mandl, I.: Serum trypsin inhibitory capacity and the idiopathic respiratory distress syndrome. J. Pediat., 81: 588 (1972).

14. Evans, H. E., Levi, M., and Mandl. I.: Serum enzyme inhibitor concentrations in the respiratory distress syndrome. Amer. Rev. Resp. Dis., 101:359 (1970).

15. Fierer. J. A.. Mandl, I., and Evans, H. E.: Alpha ${ }_{1}$-antitrypsin in the lungs of newborn infants with respiratory distress syndrome. J. Pediat. 85: 698 (1974).

16. Ganrot, P. O., and Niléhn, J. E.: Immunochemical determination of human plasminogen. Clin. Chim. Acta, 22: 335 (1968).

17. Gitlin. D., and (raig, J. M.: The nature of the hyaline membrane in asphyxia of the newborn. Pediatrics, 17:64 (1956).

18. Gluck. L., Kulovich, M. V., Borer, R. C...Jr., Brenner, P. H., Anderson, G C., and Spellacy. W. N.: The diagnosis of the respiratory distress syndrome (RDS) by amniocentesis. Amer. J. Obstet. Gynecol., 109; 440 (1971).

19. Kotas, R. V., Fazen, L. E., and Moore, T. E.: Umbilical cord serum trypsin inhibitor capacity and the idiopathic respiratory distress syndrome. J. Pediat., 81: 593 (1972)

20. Licherman, J.: The nature of the fibrinolytic enzyme defect in hyaline membrane disease. N. Engl. J. Med., 265: 363 (1961)

21. Lieberman, J.: Pulmonary plasminogen-activator activity in hyaline membrane disease. Pediat. Res., 3: 11 (1969).

22. Lowry, O. H., Rosebrough, N. J., Farr, A. L., and Randall, R. J.: Protein measurement with the Folin phenol reagent. J. Biol. Chem., 198: 265 (1951)

23. Mahasandana, C.. and Hathaway, W. E.: Circulatory anticoagulants in the newborn: Relation to hypercoagulability and the idiopathic respiratory distress syndrome. Pediat. Res., 7: 670 (1973)

24. Mathis, R. K. Freier, E. F., Hunt, C. F. Krivit, W and Sharp H L Alpha, -antitrypsin in the respiratory distress syndrome. N. Engl. J. Med. 288: $59(1973)$

25. Morgan. T. E.: Pulmonary surfactant. N. Engl. J. Med.. 284: 1185 (1971).

26. Singer, A. D.. Thibeault, D. W.. Hobel, C. J., and Heiner, D. C.: Alpha, antitrypsin in amniotic fluid and cord blood of preterm infants with the respiratory distress syndrome. J. Pediat.. 88: 87 (1976).

27. Taylor. F. B., and Abrams, M. D.: Effect of surface active lipoprotein on clotting and fibrinolysis and of fibrinogen on surface tension of surface active lipoprotein. Amer. J. Med., 40: 346 (1966).

28. Van Breeman, V. L., Neustein. H. B., and Burns, P. D.: Pulmonary hyalin membranes studies with the electron microscope. Amer. J. Pathol.. 33: 769 (1957).

29. Webb, H., and Tierney. D.: Experimental pulmonary edema due to intermittent positive pressure ventilation with high inflation pressures: Protection by positive end-expiratory pressure. Amer. Rev. Resp. Dis., 110: 556 (1974).
30. Division of Hoechst Pharmaceuticals, Inc., Somerville, N. J.

31. Informed consent was obtained from the mother.

32. Dr. A. D. Singer was a Fellow in Immunology and Allergy. Department of Pediatrics, Harbor General Hospital, when this study was carried out.

33. This research was supported in part by a grant from Hoechst Pharmaceuticals, Inc., Somerville, N. J.

34. Requests for reprints should be addressed to: D. W. Thibeault, M.D. Chief, Division of Neonatology. Department of Pediatrics, Harbor General Hospital, 1000 W. Carson St., Torrance. Calif. 90509 (USA).

35. Received for publication May 4, 1976.

36. Accepted for publication August 4, 1976 